日臨外会誌 $61 （ 8), 2191-2195,2000$

症例

下大静脈, 腸骨静脈血栓症を合併した広範囲後腹膜膿瘍の 1 例

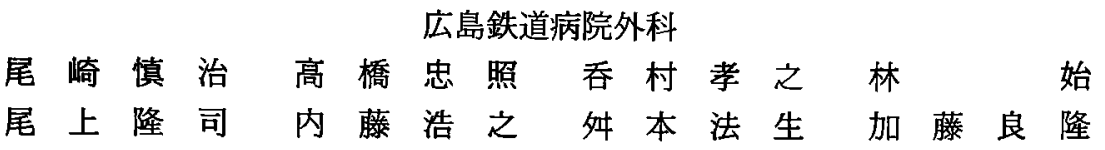

症例は54歳, 女性. 平成 11 年 2 月中旬より発熱, 左季胁部痛, 左下肢痛があり受診し た. CT 検查の結果, 左腎門部から小骨盤に及ぶ広範囲の後腹膜腔膿煌と診断された。 た左外腸骨静脈内に血栓を認めた。緊急のドレナージが必要と判断され, 同日全身麻酔 下に㗨急手術を行い, 腹膜外経路て膿瘍をドレナージした。また左外腸骨静脈血栓症に 対してはドレナージに先立ち下大静脈にフィルターを留置した。術前検査では下大静脈 の血栓は同定されなかった. 後腹膜膿瘍の原因としては糖求病による易感染性, 重度の

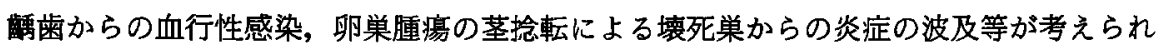
た (卵巣䧶腫の茎捻転は膿瘍ドレナージの術後に行われた子宮摘出時に診断された). 病 巣部位, 範囲の診断, 手術アプローチを選択する上で造影 CT が有用であった. また治 療法としては手術による膿瘍ドレナージ術, 肺梗塞予防のための下大静脈フィルター挿 入, 血栓溶解療法, 抗凝固療法が有効であった.

索引用語：後腹膜膿瘍, 静脈血栓症, 糖尿病

\section{緒 言}

Mynster の報告以来, 多くの腸腰筋膿傷を含めた後 腹膜膿場の報告例があるが, 抗生剤の進歩, 栄養状態 の改善, 衛生環境の向上等により現在では比較的稀な 疾患とされている.今回われわれは糖㽷病および凝固 機能異常のある患者に発生した広範囲の後腹膜膿湟に 下大静脈, 腸骨静脈血栓症を合併した稀な症例を経験 したので若干の文献的考察を加え報告する。

症例

症例：54歳, 女性.

既往歴：特記すべきことなし.

家族歴：父親が胃癌で死亡.

現病歴: 平成11年 2 月17日より37度台の発熱, 左季 肋部痛が続くため 2 月20日近医内科を受診. 内服薬投 与で左季助部痛は軽快したが，2 月22日より左下肢痛 を訴えるようになったため 2 月26日当院整形外科を受 診した。CT 検査上, 左腎門部背側から小骨盤にまで及 心広範囲の膿湟形成, 左外腸骨静脈内血栓, 左大腿部 の腫大を認めた。また子宮には類円形腫瘤が多発して おり子宮筋腫を認めた．早急のドレナージが必要と判

2000 年 2 月 9 日受付 2000 年 4 月 28 日採用
断され，手術目的として当科に緊急入院した.

入院時現症：眼瞼結膜に著名な貧血を認め, 重度の 韵菌があった。左閁径部から大眼部にかけて疼痛を訴 え, 左大腿部は著名に腫脹していた。また左下肢は伸 展困難であり，腸腰筋肢位をとっていた。

入院時検查所見：炎症反応高値, 筫血, 低栄養を認 めた（表 1). 術後の75g-OGTTでは糖尿病型 (NIDDM)を示した。

入院時腹部単純 $\mathrm{X}$ 線写真 : 左腸腰笳陰影の消失を認

\section{表 1 入院時検査所見}

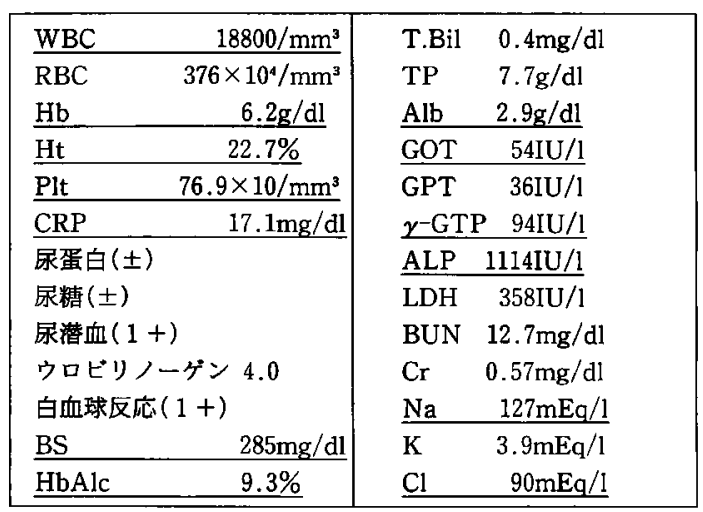


めた。

入院時腹部造影 $\mathrm{CT}$ ：左腎門部背側から左腸腰筋部 の後腹膜を伝わり小骨盤にまで及ぶ広範囲の膿湯形成 を認める(図 $1 \mathrm{a}$ )。左外腸骨動静脈は膿瘍により腹側 に圧排され変形を来しており左外腸骨静脈内には静脈 血栓が存在した (図 1 b).

手術所見：全身麻酔下にまず手術に先立ち一時的な
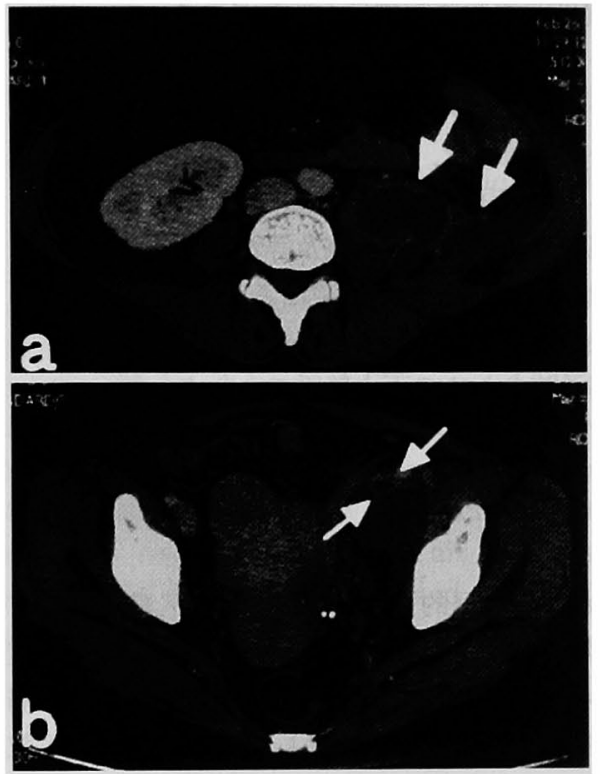

図 1 入院時腹部造影 CT：a：左腎門部から小 骨盤にまで及ぶ広範囲の膿瘍形成を認める。 b : 左外腸骨静脈内に血栓が存在する。
下大静脈フィルターをL 4 の高さに挿入した．超音波 検查で膿焬の位置を改めて検索し，膿愓が左堅下極か ら左外腸骨動静脈付近まで存在することを確認した。 体位は仰臥位とし手術を開始した，左傍腹直筋からの アプローチで後腹膜に達し，後腹膜を破らないよう注

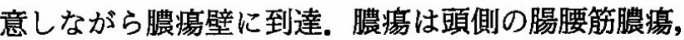
尾側の後腹膜膿場の 2 力所に分れており，膿瘍腔同士 の交通はなかった。それぞれの膿湟を排除した後，膿 瘍部前面にドレーンを留置した。

両下肢静脈造影(術後 3 日目)：左外腸骨静脈内に血 栓を認める。

肺血流シンチグラム ( $\left.{ }^{131} \mathrm{I}-\mathrm{MAA}\right)$ ：RI 集積の欠損 像は認めず，肺梗塞の所見は認めない。

下大静脈造影（永久的下大静脈フィルター挿入時）

(術後 8 日目)：第 1 および第 2 腰椎間の位置の下大 静脈内に血栓があり(図 $2 a$ ), 永久的下大静脈フィル ターは第11および第12胸椎間に留置した(図 2 b).ま た右外腸骨静脈にも血栓を認めた。

術後造影 CT（術後15日目）：膿瘍は左腸腰筋に沿っ てわずかに認められるのみとなっている(図 3 a)．左 外腸骨静脈内の血栓は消失している (図 $3 \mathbf{b}$ ).

細菌学的検查：streptococcus agalactiae が検出さ れ，結核菌は検出されなかった。

経過（図 4）：当科受診当日に緊急ドレナージ手術, 一時的下大静脈フィルター挿入を行った。術後は良好 なドレナージが得られ，抗生剤投与により臨床症状は 順調に改善した．また左外腸骨静脈血栓症を合併して いたので肺梗塞予防の目的で一時的フィルター挿入に

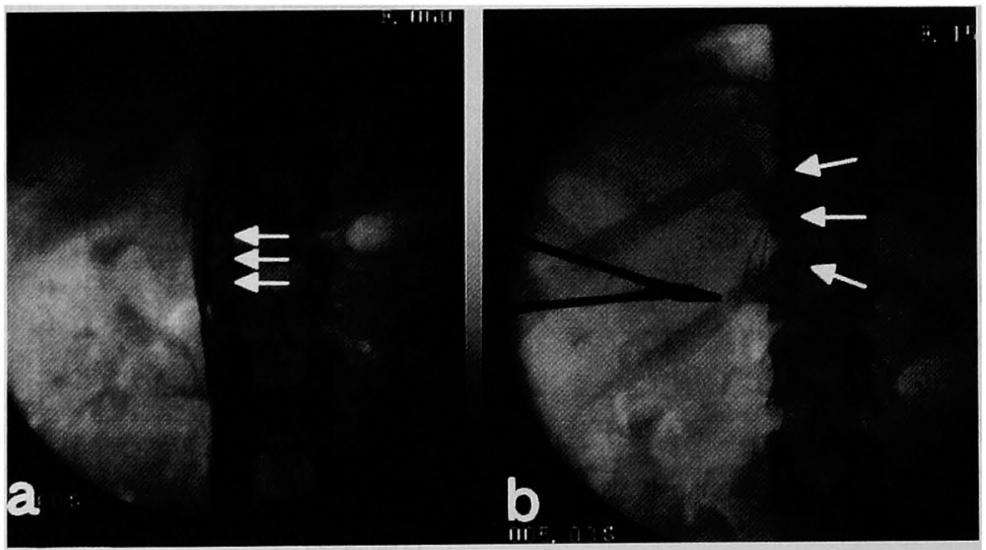

図 2 下大静脈造影： a : L 1 - 2 間の位置の下大静脈内に血栓を認める。 b : Th11-12間の位置に永久的下大静脈フィルターを留置した。 


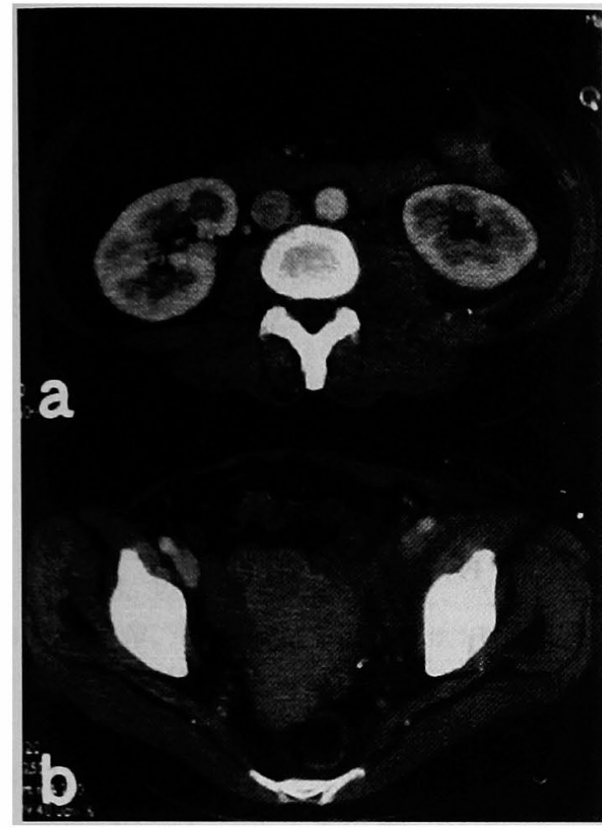

図 3 術後造影 CT：

$\mathbf{a}$ :膿瘍は左腸腰笳に沿ってわずかに認めら れるのみとなった。

b : 左外腸骨静脈内の血栓は消失している.

加え，血栓溶解療法，抗凝固療法を手術当日より開始 した。衍後の検查では更に右外腸骨静脈，下大静脈に も血栓を合併していること，凝固機能に先天的な異常 があること（表 2 ）が判明した。したがって今後血栓 症を再び起す危険性があると判断されたため下大静脈 フィルターを一時的フィルターから永久的フィルター に変更し，内服薬による抗凝固療法を継続することと した. PT 活性は70\%前後にコントロールした.術後経 過は良好であったが，術後 1 カ月目頃より大量の不正 出血を認め, 子宮筋腫からの出血と診断され，子宮摘 出術が行われた。また左卵巣敏腫茎捻転を合併してい たため左卵巣も摘出された。 その後，内科に転科して 血糖コントロールを受け退院となり，再発なく経過中 である。

\section{考察}

後腹膜膿瘍は Mynster ${ }^{1)}$ の報告以来, 多くの報告例 があるが，抗生㶡の進歩，栄養状態の改善，衛生環境 の向上等により現在では比較的稀な疾患とされてい る.

後腹膜膿瘍は原発性と続発性に分類される22. 原発 性では外傷，手術，皮膚化膿創，腰部局注，銊治療等
による血行性感染が原因となる。患者の状態としては 糖尿病，低栄養，貧血，ステロイド投与中，薬物乱用 者等が背景として挙げられる34). 起因菌としては黄色 ブドウ球菌が多い.その他ではカンジタが挙げられ， 中心静脈栄養中に起こったカンジタ血症が原因となっ た報告例もある ${ }^{5)}$.

一方続発性の場合は後腹膜隣接臟器からの炎症の波 及によって起こるものである．消化器外科領域では急 性虫垂炎, 䄭室炎, Crohn 病, 大腸癌, 膵臟癌等, 産 婦人科領域では出産後の上向性感染, 子宮摘出後等, 整形外科領域では結核性脊椎炎，骨髄炎，椎間腔への 感染等, 泌尿器科領域では腎摘後, 腎周囲膿湯, 腎盂 腎炎，膀胱腫瘍の転移等が原因となる。起因菌として は消化管を原因とする疾患が多いため E. coli のよう なグラム陰性桿菌が起因菌となることが多い. 続発性 の原因として以前は結核性脊椎炎が多く挙げられてい たが6(7), 欧米では現在 Crohn 病が最も頻度が高いと報 告されている.しかし本邦では Crohn 病の後腹膜膿瘍 合併例は比較的少なく，これは本邦での Crohn 病の治 療成績における合併症の発現率の低さ，良好な手術経 過に基づくと報告されている゙

本症例の後腹膜膿湯の原因としては糖尿病による易 感染性，重度の薭歯からの血行性感染，卵巣腫瘍の茎 捻転による壤死巣からの炎症の波及等が考えられた。 血栓症を合併していた原因は先天的な凝固異常に加 え，膿痬による炎症の波及が考えられた，起因菌は streptococus agalactiae であった，検索しえた限りで は後腹膜膿瘍に静脈血栓症を合併した報告例は本邦, 欧米を通じて原発性，続発性それぞれ 1 例づつあるの みであり，本症例は極めて稀な症例と考えられる ${ }^{8) 99}$.

後腹膜膿瘍の症状としては発熱, 下腹部痛, 鼠径部 の疼痛, 腰痛, 患側の下肢痛, 腸腰筋肢位（患側股関 節の屈曲拘縮）等が挙げられる.

診断上特徵的な画像所見としては，X線検査では患 側の腸腰筋陰影の腫大，不鮮明化が，超音波検查では 周囲との境界が明瞭な echo free space が確認される. 造影 CT, MRI 検査は超音波検査と比較し後腹膜腔の 構造物の描出に優れ, 病巣部位, 範囲, 隣接臓器との 関係, 手術適応の決定, 手術の際の到達経路の選択に 有用である。また手術後の治潦効果等, 手術後のフォ ローにも役立つ ${ }^{1011 !}$ ．本症例においては CT 検査によ り，かなり広範囲な後腹膜膿湟であると診断されたた め，手術による早急なドレナージが必要であると判断 された。また超音波検査でおおよその膿瘍の範囲を同 


\section{抗凝固療法}

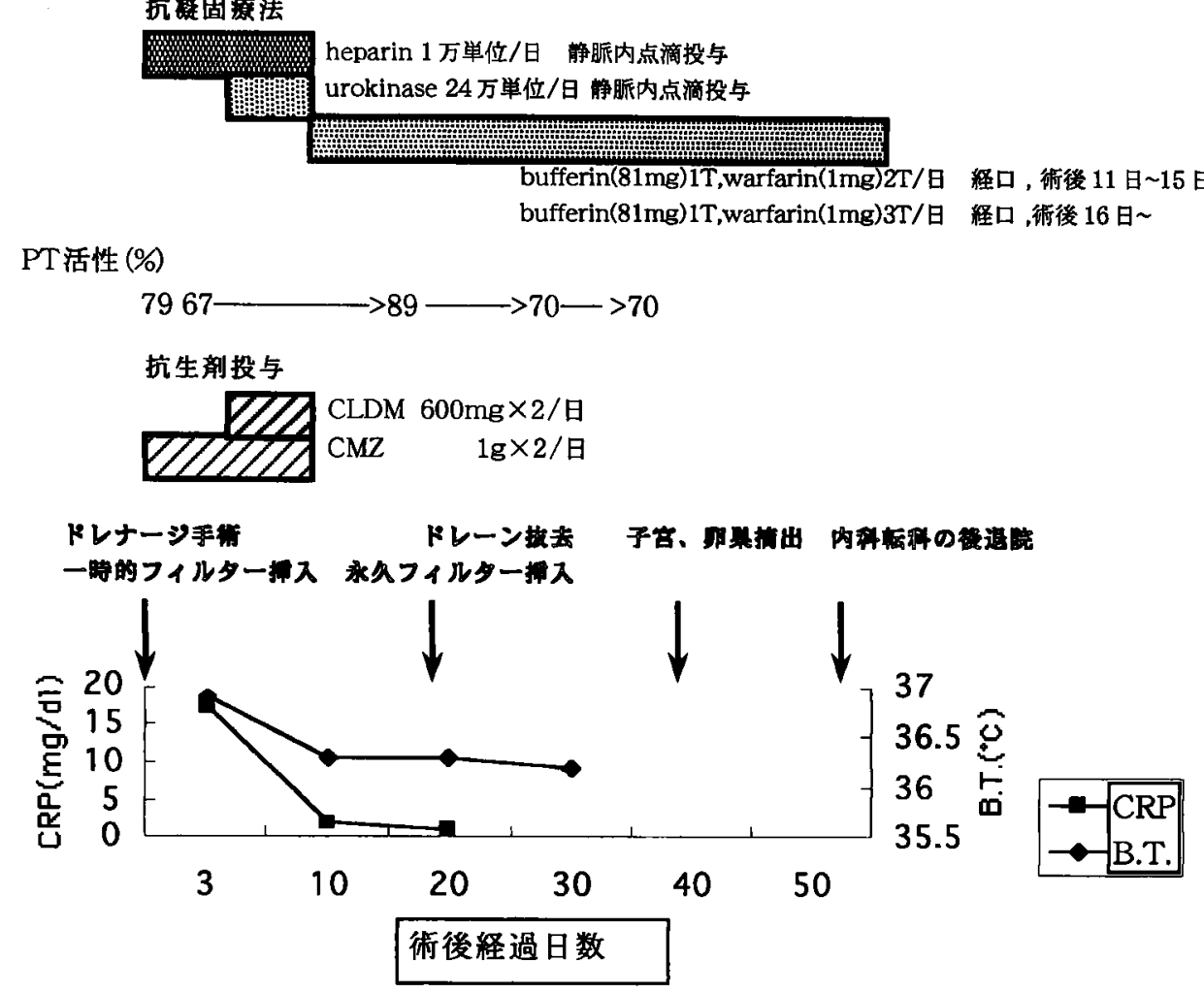

図 4 経過表

表 2 凝固系検查

\begin{tabular}{|l|c|c|}
\hline \multicolumn{1}{|c|}{ 検査項目 } & 結果 & 基準值 \\
\hline protein C 抗原量 & 84 & $70-150$ \\
protein C 活性 & $\frac{48}{116}$ & $55-140$ \\
protein S 抗原量 & $116-135$ \\
\hline lupus anticoagulant & 陽性 & 陰性 \\
\hline カルシ்オリピンIg-G抗体 & $<0.5$ & $<1.0$ \\
カルジオリピンIg-M抗体 & $<0.5$ & $<1.0$ \\
\hline 出血時間 & 1 分30秒 & 1 分〜 3 分 \\
\hline PT time & 12.1 秒 & $10.5 \sim 13.0$ 秒 \\
\hline PT活性 & $78 \%$ & $\geqq 70 \%$ \\
\hline
\end{tabular}

定でき，手術時に病巣への到達経路の決定に有用であ つた。

治療は抗生物質投与と早急なドレナージ術が必要と される.限局された病変であっても敗血症を併発し， 死亡した報告もある4). 原発性では腹膜外経路でのド レナージ術, 続発性では原発巣の治療とあわせたドレ
ナージ術が基本的治療であるが，最近では全身麻酔下 の手術を行えないような全身状態不良な症例に対して 局所麻酔下で行う超音波，CTガイド下での経皮的ド レナージによる治療例が増加し，良好な成績をあげて いる．原発性の単純な膿瘍，続発性膿瘍の第一選択と しての治療, 腸切除が必要な合併症を起こした澧崵の 治療としてまず行われるべき治療といえる12).

再発症例，超音波あるいはCT ガイド下での経皮的 ドレナージによる治療無効症例, Crohn 病に合併した 複雑な膿瘍の症例では手術によるドレナージの適応と なる11).

本症例では CT 検査の結果，かなり広範囲な原発性 後腹膜膿瘍であると診断されたため，手術による早急 なドレナージが必要であると判断され，全身麻醉下， 腹膜外経路でのドレナージ術を行った。また本症例て は術前に左外腸骨静脈血栓症を合併していることが判 明しており，手術に先立ち，肺梗塞予防として一時的 下大静脈フィルター㨂入を行った。 


\section{結 語}

1. 糖尿病および疑固機能異常のある患者に発生し た下大静脈，腸骨静脈血栓症を合併した広範囲後腹膜 膿場の 1 例を経験した。

2. 治療法として手術による膿痬ドレナージ術，肺 梗塞予防としての下大静脈フィルター挿入, 血栓溶解 療法, 抗凝固療法が有効であった。

$$
\text { 文献 }
$$

1) Mynster $\mathrm{H}$ : Acute psoitis. J Buffalo Med Surg $21: 202-210,1881$

2）高木幸浩, 阿部達彦, 前田雅人他：急性虫垂炎に よる高齢者の腸腰筋膿場の 1 例. 外科 $54: 1241$ $-1243,1992$

3）仲地 厚, 木田栄郎, 脇 慎治他：精尿病に併発 した腸腰筋膿煬の 1 例。日臨外医会誌 $56: 1068$ $-1071,1995$

4) Thomas $R$ Walsh : Changing Etiology of iliopsoas abscess. Am J Surg 163: 413-416, 1992

5）勘也寸志, 帯刀圭子: 後腹膜膿場に続発した感染 性総腸骨動脈瘤を合併した慢性膵炎による䌅尿病 の 1 例. 楉尿病 $39: 867-871,1996$
6）渡辺文利, 本田 聡, 窪田裕幸他：左腸腰筋澧煌 を合併したクローン病の 1 例．日消病会誌 94 ： 597-602, 1997

7）坪庭直樹, 过畑正雄, 三宅 修他：結核性陽腰筋 膿瘍の 1 例。住友病医誌 $22: 70-73,1995$

8) Arai $Y$, Kawakami $T$, Soga $H$, et al: Psoas abscess associated with iliac vein thrombosis and piriformis and gluteal abscesses. Int $\mathrm{J}$ Urol $6: 257-259,1999$

9) C Wittram: Sigmoid diverticulitis presenting as unilateral iliofemoral vein thrombosis. Abdomen Imaging $19: 257-258,1994$

10）澤田 傑, 石川 真, 関野昌宏：皮下膿演を形成 した原発性巨大腸腰筋膿場の 1 例. 日臨外医会誌 $58: 681-684,1997$

11) Wiliam Mcauliffe: Thendiagnosis and treatment of psoas abscess : A 12 year review. Aust $\mathrm{Nz}$ J Surg 64 : 413-417, 1994

12）内納正一, 高下光弘, 平川 敬他：エコー下経皮 的ドレナージによる腸腰筋膿瘍の治療経験. 整外 と災外 $45: 332-335,1996$

\title{
A CASE OF WIDESPREADED RETROPERITONEAL ABSCESS ASSOCIATED WITH INFERIOR VENA CAVA AND EXTERNAL ILIAC VEIN THROMBOSIS
}

\author{
Shinji OZAKI, Tadateru TAKAHASHI, Takayuki NOMIMURA, \\ Hajime HAYASHI, Takashi ONOE, Hiroyuki NAITO, \\ Norio MASUMOTO and Yoshitaka KATO \\ Department of Surgery, Hiroshima General Hospital of West Japanese Railway Company
}

A 54-year-old woman was admitted to the hospital because of fever elevation, left hypochondralgia and left femoral pain in December 1999. As a result of ultrasound and enhanced computed tomography, she was diagnosed as having a widespreaded retroperitoneal abscess ranging from the left kidney to small pelvis associated with left external iliac vein thrombosis. We decided that she needed emergency drainage of the abscess and under general anesthesia the drainage was performed extraperitoneally. In advance an inferior vena cava filter was detained because of complication of external iliac vein thrombosis. In the angiography after the operation, she was also found having a inferior vena cava thrombosis. In this case the cause of abscess was assumed to be immune deficiency resulting from diabetes, hematogenous infection on the basis of her severe dental caries or affection of inflammation from the necrosis site of an ovarian cyst. In this case, contrast enhanced CT was helpful in diagnosing location of the lesion and the range to be involved in operation, and in selecting operative approsch. Surgical abscess drainage, insertion of an inferior vena cava filter to prevent pulmonary infarction, thrombolytic therapy and anticoagulant therapy were of beneficial. A case of widespreaded retroperitoneal abscess with vein thrombosis was reported with a brief review of the literature. 